\title{
Effect of breed on production, carcass traits and meat quality of Aberdeen Angus, Limousin and Aberdeen AngusxLimousin bulls offered a grass silage-grain-based diet
}

\author{
Maiju Pesonen ${ }^{1}$, Markku Honkavaara ${ }^{2}$ and Arto Huuskonen ${ }^{1}$ \\ ${ }^{1}$ MTT Agrifood Research Finland, Animal Production Research, FI-92400 Ruukki, Finland \\ ${ }^{2}$ Finnish Meat Research Institute, P O Box 56, Fl-13101, Hämeenlinna, Finland \\ e-mail: maiju.pesonen@mtt.fi
}

\begin{abstract}
The objective of the experiment was to study the performance, carcass traits and meat quality of purebred Aberdeen Angus ( $\mathrm{Ab}$ ) and Limousin (Li) bulls and $\mathrm{Ab} \times \mathrm{Li}$ crossbred bulls offered grass silage-grain-based rations and raised to heavy carcass weights. The experiment included eight bulls in all breed groups. The average slaughter age for all breeds was 540 days and the mean carcass weights for the Ab, AbxLi and Li bulls were 391, 399 and $439 \mathrm{~kg}$, respectively. Significant breed differences in carcass traits and meat quality were observed. The Limousin bulls tended to achieve a higher conformation score, produced less fat and had a higher percentage of valuable cuts compared with the Aberdeen Angus bulls. The crossbred AbxLi bulls produced better conformed carcasses and a higher share of the rounds compared to the pure Ab bulls which indicate that this type of crossbreeding can enhance beef production under the studied conditions.
\end{abstract}

Key words: Beef production, breeds, bulls, carcass characteristics, eating quality, growth

\section{Introduction}

Traditionally most beef in Finland has been produced by dairy breeds. However, the decrease in the dairy cattle population observed in recent years threatened to reduce the level of beef production, and production from beef breed calves is increasing at present. Because of the falling supply of domestic beef, there is nowadays a clear discrepancy between the demand for and supply of domestic beef. Consequently, slaughterhouse pricing favours heavy carcasses and the average carcass weights of slaughtered animals have clearly increased in Finland during recent years. For example, the average carcass weight of slaughtered bulls (including both dairy and beef breeds) increased from $275 \mathrm{~kg}$ (1996) to $335 \mathrm{~kg}$ (2008) in twelve years (Karhula and Kässi 2010). Currently in Finland, beefbreed bulls are typically slaughtered at carcass weights of approximately $400 \mathrm{~kg}$ (Huuskonen et al. 2012). However, there is lack of published information on the growth, carcass traits and meat quality parameters of beef bulls slaughtered at such high carcass weights.

Carcass composition (proportions of muscle, fat and bone) largely determines carcass value. A high proportion of muscle with a low proportion of bone and an optimum level of fat (dictated by local consumer preferences) represent a superior carcass (Oprządek et al. 2001). The distribution of muscle, bone and fat is largely a function of maturity (Robelin 1986). Most phenotypic conformation differences between beef cattle types are due to differences in maturity, as well as muscle, bone and fat share and distribution. Cattle at the same maturity stage demonstrate a higher variation in the distribution of fat than of any other tissue (Berg et al. 1978). Differences between individual beef breeds in performance, carcass traits and meat quality have been recently evaluated, for example, by Chambaz et al. (2003), Bartoň et al. (2006), Cuvelier et al. (2006a,b) and Alberti et al. (2008). In addition, numerous research reports have been published on the performance of different sire breeds compared in crossbreeding trials, for example, in Great Britain (Kempster et al. 1982, 1988), Norway (Aass and Vangen 1998, Rødbotten et al. 2002), Czech Republic (Sŭbrt et al. 1999, Poláh et al. 2004) and United States (Koch et al. 1982, Wheeler et al. 1996). However, in Finland, less research has been carried out, and there is a paucity of information on the effects of breed on the performance, carcass traits and meat quality of beef-breed bulls raised to heavy carcass weights with typical Finnish grass silage-grain based rations. Therefore, the objective of the present experiment was to study the growth, carcass characteristics, valuable cuts and meat quality parameters of purebred Aberdeen Angus and Limousin bulls and Aberdeen AngusxLimousin crossbred bulls, and to evaluate the potential for improvement of carcass and meat quality through this type of crossbreeding compared to purebred Aberdeen Angus bulls. 


\section{Materials and methods \\ Animals, housing and feeding}

The experiment was conducted on the affiliated farm of the North Ostrobothnia Research Station of MTT Agrifood Research Finland (Lapinlahti, $63^{\circ} 21^{\prime} \mathrm{N}, 27^{\circ} 24^{\prime} \mathrm{E}$ ). The experiment started in December 2010, ended in November 2011, and comprised in total 8 Aberdeen Angus bulls, 8 Limousin bulls and 8 Aberdeen Angus $\times$ Limousin (Aberdeen Angus dams sired by Limousin) crossbred bulls. The bulls in all breed groups were from three different sires so they would cover variation in their respective populations. All the animals, initial live weight (LW) $285 \pm 38.0 \mathrm{~kg}$ (Ab), $276 \pm 36.8(\mathrm{Ab} \times \mathrm{Li})$ and $325 \pm 18.7 \mathrm{~kg}(\mathrm{Li})$, were spring-born calves purchased from commercial suckler herds. During their first summer all the calves had been kept on pasture together with their dams. At the start of the experiment the animals were 184 days old, on average. Throughout the experiment, bulls of each breed were housed in the same pen ( 8 animals per pen, $8.0 \mathrm{~m}^{2}$ per bull) in an uninsulated barn with straw bedding.

The animals were offered grass silage ad libitum (proportionate refusals as 5\%) and a mixture of rolled barley and oats (1:1 on dry matter (DM) basis). The target for average concentrate level during the experiment was 400 $\mathrm{g} \mathrm{kg}^{-1} \mathrm{DM}$. The daily ration for the bulls included also $150 \mathrm{~g}$ of a mineral mixture (A-Rehu Ltd., P.O. Box 908, FI60061 Atria, Finland: KasvuApeKivennäinen: Ca 260, P 0, Na 70, Mg $35 \mathrm{~g} \mathrm{~kg}^{-1}$ ). The feed intake was not measured exactly because the bulls of each breed were housed in the same pen and there were no individual observations of feed intake. Feed sub-samples for chemical analyses were pooled over periods of eight weeks and analysed for DM, crude protein (CP), neutral detergent fibre (NDF) and digestible organic matter (DOM) in DM (D value). Feed DM values were determined by oven drying. Silage DM was corrected for loss of volatiles (Huida et al. 1986). Crude protein, NDF and D value were determined by near-infrared spectroscopy as described by Nousiainen et al. (2004). The silage was analysed also for fermentation quality ( $\mathrm{pH}$, water-soluble carbohydrates (WSC), lactic and formic acids, volatile fatty acids, soluble and ammonia $\mathrm{N}$ content of $\mathrm{N}$ ) by electrometric titration as described by Moisio and Heikonen (1989).

The metabolizable energy (ME) contents of the feeds were calculated according to the Finnish feed tables (MTT 2012). The ME value of the silage was calculated as $0.016 \times D$ value (MTT 2012). The ME values of the concentrates were calculated based on concentrations of digestible crude fibre, $\mathrm{CP}$, crude fat and nitrogen-free extract described by MAFF (1984). The digestibility coefficients of the concentrates were taken from the Finnish feed tables (MTT 2012). The values of amino acids absorbed from the small intestine (AAT) and the protein balance in the rumen (PBV) were calculated according to the Finnish feed tables (MTT 2012).

The grass silage used in the present experiment was of good nutritional quality as indicated by the $D$ value as well as the AAT and CP contents (Table 1). The fermentation characteristic of the silage was also good as indicated by the $\mathrm{pH}$ value and the low concentration of ammonia $\mathrm{N}$ and total acids. The silage used was restricted fermented with high residual WSC concentration and low lactic acid concentration. The concentrate feeds used had typical chemical composition and feed values (Table 1).

\section{Live weight, slaughter procedures and meat quality measurements}

The animals were weighed on two consecutive days at the beginning of the experiment and thereafter approximately every 56 days. Before slaughter they were weighed on two consecutive days. The target for average slaughter age in the experiment was 18 months (540 days) which is the average slaughter age for beef bulls in Finland (Huuskonen et al. 2012). The live weight gain (LWG) was calculated as the difference between the means of initial and final live weights divided by the number of growing days. The estimated rate of carcass gain was calculated as the difference between the final carcass weight and the carcass weight in the beginning of the experiment divided by the number of growing days. Carcass weight in the beginning of the experiment was assumed to be 0.50 x initial LW, which was used also in studies by Root and Huhtanen (1998) and Huuskonen et al. (2009) and which was assessed based on earlier studies (unpublished data).

The animals were slaughtered in the Atria slaughterhouse in Kuopio. Carcasses were electrically stimulated during debleeding (low voltage of $70 \mathrm{~V}$ ). After slaughter the carcasses were weighed hot and the cold carcass weight was estimated as 0.98 of the hot carcass weight. Dressing proportions were calculated from the ratio of cold carcass weight to final LW. The carcasses were classified for conformation and fatness using the EUROP quality classification (Commission of the European Communities 1982). For conformation, development of carcass profiles, 
in particular the essential parts (round, back, shoulder), was taken into consideration according to the EUROP classification (E: excellent, U: very good, R: good, O: fair, P: poor), and for fat cover degree the amount of fat on the outside of the carcass and in the thoracic cavity was taken into account using a classification range from 1 to 5 (1: low, 2: slight, 3: average, 4: high, 5: very high). Each level of the conformation scale was subdivided into three sub-classes $(\mathrm{O}+, \mathrm{O}, \mathrm{O}-)$ to produce a transformed scale ranging from 1 to 15 , with 15 being the best conformation.

\begin{tabular}{|c|c|c|c|}
\hline & $\begin{array}{l}\text { Grass } \\
\text { silage }\end{array}$ & Barley & Oats \\
\hline$N^{a}$ & 8 & 4 & 4 \\
\hline Dry matter (DM), $\mathrm{g} \mathrm{kg}^{-1}$ feed & 381 & 863 & 871 \\
\hline Crude protein, $\mathrm{g} \mathrm{kg}^{-1} \mathrm{DM}$ & 164 & 123 & 138 \\
\hline Neutral detergent fibre, $\mathrm{g} \mathrm{kg}^{-1} \mathrm{DM}$ & 556 & 210 & 310 \\
\hline Metabolizable energy, $\mathrm{MJ} \mathrm{kg}^{-1} \mathrm{DM}$ & 10.9 & 13.2 & 11.5 \\
\hline $\mathrm{AAT}^{\mathrm{b}}, \mathrm{g} \mathrm{kg}^{-1} \mathrm{DM}$ & 84 & 97 & 91 \\
\hline $\mathrm{PBV}^{\mathrm{c}}, \mathrm{g} \mathrm{kg}^{-1} \mathrm{DM}$ & 40 & -23 & 5 \\
\hline Digestible organic matter in DM, $\mathrm{g} \mathrm{kg}^{-1} \mathrm{DM}$ & 681 & $N^{d}$ & $N D^{d}$ \\
\hline \multicolumn{4}{|l|}{ Fermentation quality of grass silage } \\
\hline $\mathrm{pH}$ & 4.62 & & \\
\hline Volatile fatty acids, $\mathrm{g} \mathrm{kg}^{-1} \mathrm{DM}$ & 11 & & \\
\hline Lactic + formic acid, $\mathrm{g} \mathrm{kg}^{-1} \mathrm{DM}$ & 21 & & \\
\hline Water soluble carbohydrates, $\mathrm{g} \mathrm{kg}^{-1} \mathrm{DM}$ & 69 & & \\
\hline \multicolumn{4}{|l|}{ In total $\mathrm{N}, \mathrm{g} \mathrm{kg}^{-1}$} \\
\hline $\mathrm{NH}_{4} \mathrm{~N}$ & 36 & & \\
\hline Soluble N & 327 & & \\
\hline
\end{tabular}

After classification carcasses were chilled overnight below $7{ }^{\circ} \mathrm{C}$. Day after slaughter the right side of carcasses were commercially cutted. Primal cuts were forequarter, back, side and round. During subdividing of forequarter and back the quality of entrecote (Musculus longissimus thoracis between the 4th and the 7th rib) and loin (Musculus longissimus lumborum between the 7th rib and the 3rd lumbar vertebra) were evaluated, respectively. The marbling score was determined subjectively using a six-point scale ( $0=$ devoid to $5=$ =abundant) at the 7 th rib in the entrecote and at the 1 st lumbar vertebra in the loin (after cutting a $2 \mathrm{~kg}$ sample from the posterior part of loin). pH-value of the loin was measured with a Knick 651 instrument with Inlab Solid electrode (Mettler Toledo). Instrumental colour measurements were recorded for L* (lightness; 0: black, 100: white), a* (redness/greenness; positive values: red, negative values: green), and $b^{*}$ (yellowness/blueness; positive values: yellow; negative values: blue) using a Minolta ChromaMeter Cr200 (Minolta Camera Co., Ltd., Osaka, Japan). The bloom time was half an hour. The Minolta CR200 was calibrated to a standard white plate. CIE Standard Illuminant D65 conditions were used for the measurements.

The right side of each carcass was cut into valuable cuts [outside round, inside round, corner round, roast beef (Musculus gluteus medius), tenderloin, loin and entrecote], subcutaneous fat and bones as described by Manninen et al. (2011). All cuttings, subcutaneous fat and bones were weighed and their yields were expressed as percentages of the carcass cold weight $(0.98 \times$ carcass hot weight, 50 min post mortem). During cutting, a $2 \mathrm{~kg}$ loin (Musculus longissimus lumborum between the 7 th rib and the 3 rd lumbar vertebra) sample was vacuum packaged. After that, samples were sent to the Finnish Meat Research Institute (LTK) for further analyses. At LTK, loin samples were aged for 8 days at $4{ }^{\circ} \mathrm{C}$. Then samples analysed for moisture, protein and intramuscular fat contents, drip loss, 
Warner-Bratzler shear force and for subjective tenderness, juiciness and beef flavour (sensory analysis). Moisture, protein and intramuscular fat contents were determined as described by Huuskonen et al. (2010). For shear force measurements loin samples were heated in a water bath at $85^{\circ} \mathrm{C}$ until the core temperature of the meat was 70 ${ }^{\circ} \mathrm{C}$. After chilling for 24 hours $\left(4^{\circ} \mathrm{C}\right)$, loin samples about $6 \mathrm{~cm}$ long (parallel to the myofiber direction), $1 \mathrm{~cm}$ high and $1 \mathrm{~cm}$ wide (square probe of $1 \mathrm{~cm} \times 1 \mathrm{~cm}$ surface area) were placed in a Warner-Bratzler shear blade to be sheared perpendicular to the longitudinal axis of the muscle fibres in an Instron testing machine (Instron model 4301 with cross head speed of $200 \mathrm{~mm} \mathrm{~min}^{-1}$ ). The maximum force was recorded and results were expressed as $\mathrm{kg}$ $\left(\mathrm{cm}^{2}\right)^{-1}$ (Honkavaara et al. 2003). For the sensory analysis, four $1.5 \mathrm{~mm}$ thick slices from each sample were heated to $68{ }^{\circ} \mathrm{C}$ in a rolling grill (Palux Rotimat, Germany) and evaluated by six trained sensory panelists for tenderness, juiciness and beef flavour. These traits were scored on a seven-point scale (1=low, 7=high). Drip loss was evaluated by weighing the amount of water left in the vacuum package after eight days storage.

\section{Statistical methods}

The results are shown as least squares means. The normality of residuals was checked using graphical methods: box-plots and scatter plots of residuals and fitted values. For parameters that were measured several times per individual (longissimus lumborum samples for share force and sensory analysis) all repeated measures on an animal were summarized, and then the average used for the statistics (one single value per animal). The data were subjected to analysis of variance using the SAS GLM procedure (version 9.1, SAS Institute Inc., Cary, NC). Differences among the breeds were compared using Tukey's $t$-test.

\section{Results}

The experiment lasted 345, 353 and 385 days for the Ab, Li and AbxLi bulls, respectively, and there were no significant differences in final LW between breeds (Table 2). The average slaughter age in the experiment was 545 days and close to that pre-planned. There were no differences in LWG between breeds, but the carcass gain of the Li bulls was $16 \%$ higher than that of the AbxLi bulls $(p<0.01)$. The carcass weight of the Li bulls was 10 and $12 \%$ higher than that of the $\mathrm{Ab} \times \mathrm{Li}$ and $\mathrm{Ab}$ bulls $(p<0.01)$, respectively. The dressing proportion of the Li bulls was $8 \%$ higher than that of the AbxLi and Ab bulls $(p<0.001)$, and the carcass fat score of the Li bulls was clearly lower than that of the $\mathrm{Ab} \times \mathrm{Li}$ and $\mathrm{Ab}$ bulls $(p<0.001)$. In carcass conformation, all breeds differed significantly from each other. The conformation score of the Li bulls was 80 and $46 \%$ better than that of the Ab and AbxLi bulls, respectively $(p<0.001)$. In addition, the carcass conformation score of the AbxLi bulls was $23 \%$ higher than that of the Ab bulls $(p<0.001)$ (Table 2$)$.

Breed had a clear effect on the amount $(\mathrm{kg})$ and yield (\%) of valuable cuts (Table 2). The yields of tenderloin $(p<0.001)$ and entrecote $(p=0.07)$ from the Li bulls were 43 and $25 \%$ (tenderloin) and $12 \%$ (entrecote) higher than those from the Ab and AbxLi bulls, respectively. The yield of loin was $13 \%$ higher $(p<0.01)$ from Li than from Ab bulls. Regarding the yields of outside round, inside round and corner round all the breeds differed significantly from each other (Table 2). For the Li bulls the yields of outside round, inside round and corner round were 28, 33 and $17 \%$ higher than those for the Ab bulls, and 16,16 and $13 \%$ higher than those for the Abx Li bulls, respectively $(p<0.001)$. In addition, for the AbxLi bulls the yields of outside round, inside round and corner round were 10, 15 and $3 \%$ higher than those for the purebred $A b$ bulls, respectively.

In the $\mathrm{Li}$ and $\mathrm{Ab} \times \mathrm{Li}$ bulls the yield of roast beef was 27 and $20 \%$ higher than that in the Ab bulls, respectively $(p<0.001)$. The yield of subcutaneous fat was 34 and $132 \%$ higher in the Ab bulls than in the AbxLi and Li bulls, respectively $(p<0.001)$. Furthermore, the yield of subcutaneous fat was $74 \%$ higher in the AbxLi bulls than in the Li bulls $(p<0.001)$. There were no significant differences in the yield of bones between Ab and AbxLi bulls. However, in the $A b$ and $A b \times$ Li bulls the yield of bones was 10 and $7 \%$ higher than that in the Li bulls, respectively $(p<0.001)$.

Breed had no significant effect on the $\mathrm{pH}$ of the longissimus lumborum, but the $\mathrm{pH}$ for the Ab bulls tended to be higher than for the AbxLi bulls ( $p=0.07$ ) (Table 3). The longissimus lumborum muscle of the Li bulls had higher moisture (752 vs. $737 \mathrm{~g} / \mathrm{kg}, p<0.05)$ and protein ( $218 \mathrm{vs.} 211 \mathrm{~g} / \mathrm{kg}, p<0.05)$ and lower fat ( $21 \mathrm{vs.} 38 \mathrm{~g} / \mathrm{kg}, p<0.001)$ contents than that of the Ab bulls. Additionally, the longissimus lumborum muscle of the AbxLi bulls had $57 \%$ higher fat content than the Li bulls $(p<0.001)$. The treatments had no significant effects on the drip loss or shear force value of the bulls (Table 3). Furthermore, breed had no significant effects on the sensory analysis (tenderness, juiciness or beef flavour) of the longissimus lumborum muscle. 
Table 2. Effect of breed on growth performance, carcass characteristics and valuable cuts (half carcass) of growing bulls. Between-breed comparisons (Tukey, $p<0.05$ ): estimated means with the different letters were significantly different $(p<0.05)$.

\begin{tabular}{|c|c|c|c|c|c|}
\hline & \multicolumn{3}{|l|}{ Breed } & \multirow[b]{2}{*}{ SEM } & \multirow[b]{2}{*}{$p$-value } \\
\hline & $A B$ & $\mathrm{LI}$ & $A B \times L I$ & & \\
\hline Number of animals & 8 & 8 & 8 & & \\
\hline Age at slaughter, $d$ & 526 & 561 & 547 & 10.9 & 0.091 \\
\hline Duration of the experiment, $d$ & $345^{a}$ & $353^{\mathrm{ab}}$ & $385^{b}$ & 10.2 & 0.027 \\
\hline Initial live weight, kg & $285^{\mathrm{ab}}$ & $325^{b}$ & $276^{\mathrm{a}}$ & 11.4 & 0.015 \\
\hline Final live weight, kg & 705 & 732 & 718 & 14.9 & 0.454 \\
\hline Live weight gain $\mathrm{g} \mathrm{d}^{-1}$ & 1224 & 1154 & 1152 & 41.5 & 0.394 \\
\hline Carcass gain, $\mathrm{g} \mathrm{d}^{-1}$ & $726^{\mathrm{ab}}$ & $785^{b}$ & $679^{a}$ & 21.7 & 0.009 \\
\hline \multicolumn{6}{|l|}{ Carcass characteristics } \\
\hline Carcass weight, kg & $391^{\mathrm{a}}$ & $439^{b}$ & $399^{a}$ & 8.2 & 0.001 \\
\hline Dressing proportion, $\mathrm{g} \mathrm{kg}^{-1}$ & $555^{\mathrm{a}}$ & $600^{b}$ & $555^{a}$ & 4.3 & $<0.001$ \\
\hline Conformation score, EUROP & $7,4^{\mathrm{a}}$ & $13,3^{c}$ & $9,1^{b}$ & 0.31 & $<0.001$ \\
\hline Fat score, EUROP & $3,8^{b}$ & $2,1^{\text {a }}$ & $3,3^{b}$ & 0.19 & $<0.001$ \\
\hline \multicolumn{6}{|l|}{ Valuable cuts of half carcass } \\
\hline Tenderloin, kg & $2.1^{\mathrm{a}}$ & $3.0^{\mathrm{b}}$ & $2.4^{\mathrm{a}}$ & 0.08 & $<0.001$ \\
\hline$\%$ yield & $1.1^{\mathrm{a}}$ & $1.3^{b}$ & $1.2^{\mathrm{a}}$ & 0.04 & $<0.001$ \\
\hline Loin, kg & $6.0^{\mathrm{a}}$ & $7.7^{\mathrm{b}}$ & $6.7^{\mathrm{a}}$ & 0.23 & $<0.001$ \\
\hline$\%$ yield & $3.1^{\mathrm{a}}$ & $3.5^{\mathrm{b}}$ & $3.3^{\mathrm{ab}}$ & 0.08 & 0.003 \\
\hline Entrecote, kg & $3.4^{\mathrm{a}}$ & $4.1^{\mathrm{b}}$ & $3.4^{\mathrm{b}}$ & 0.12 & $<0.001$ \\
\hline$\%$ yield & 1.7 & 1.9 & 1.7 & 0.05 & 0.065 \\
\hline Outside round, $\mathrm{kg}$ & $11.5^{\mathrm{a}}$ & $16.3^{\mathrm{c}}$ & $12.9^{\mathrm{b}}$ & 0.34 & $<0.001$ \\
\hline$\%$ yield & $5.8^{\mathrm{a}}$ & $7.4^{c}$ & $6.4^{b}$ & 0.12 & $<0.001$ \\
\hline Inside round, $\mathrm{kg}$ & $6.4^{\mathrm{a}}$ & $9.7^{c}$ & $7.7^{\mathrm{b}}$ & 0.28 & $<0.001$ \\
\hline$\%$ yield & $3.3^{\mathrm{a}}$ & $4.4^{c}$ & $3.8^{b}$ & 0.11 & $<0.001$ \\
\hline Corner round, $\mathrm{kg}$ & $5.8^{\mathrm{a}}$ & $7.9^{\mathrm{b}}$ & $6.3^{\mathrm{a}}$ & 0.20 & $<0.001$ \\
\hline$\%$ yield & $3.0^{\mathrm{a}}$ & $3.5^{\mathrm{c}}$ & $3.1^{\mathrm{b}}$ & 0.05 & $<0.001$ \\
\hline Roast beef, kg & $3.0^{\mathrm{a}}$ & $4.2^{\mathrm{b}}$ & $3.5^{b}$ & 0.14 & $<0.001$ \\
\hline$\%$ yield & $1.5^{\mathrm{a}}$ & $1.9^{\mathrm{b}}$ & $1.8^{\mathrm{b}}$ & 0.05 & $<0.001$ \\
\hline Subcutaneous fat, $\mathrm{kg}$ & $15.5^{c}$ & $7.4^{\mathrm{a}}$ & $12.0^{\mathrm{b}}$ & 0.96 & $<0.001$ \\
\hline$\%$ yield & $7.9^{c}$ & $3.4^{\mathrm{a}}$ & $5.9^{b}$ & 0.47 & $<0.001$ \\
\hline Bones, kg & 36.0 & 36.7 & 35.7 & 0.82 & 0.676 \\
\hline$\%$ yield & $18.2^{\mathrm{b}}$ & $16.6^{\mathrm{a}}$ & $17.8^{b}$ & 0.30 & 0.003 \\
\hline
\end{tabular}

Carcass conformation score: $(1=$ poor, $15=$ excellent $)$.

Carcass fat score: $(1=$ low, $5=$ very high $)$. 
Table 3. Effect of breed on meat quality of Musculus longissimus lumborum. Between-breed comparisons (Tukey, $p<0.05)$ : estimated means with the different letters were significantly different $(p<0.05)$.

\begin{tabular}{|c|c|c|c|c|c|}
\hline & \multicolumn{3}{|l|}{ Breed } & \multirow[b]{2}{*}{ SEM } & \multirow[b]{2}{*}{$p$-value } \\
\hline & $A B$ & $\mathrm{LI}$ & $A B \times L I$ & & \\
\hline Number of animals & 8 & 8 & 8 & & \\
\hline $\mathrm{pH}$ (24 h post mortem) & 5.62 & 5.58 & 5.53 & 0.024 & 0.066 \\
\hline \multicolumn{6}{|l|}{ Chemical composition, $\mathrm{g} \mathrm{kg}^{-1}$} \\
\hline Moisture & $737^{\mathrm{a}}$ & $752^{b}$ & $748^{\mathrm{ab}}$ & 3.2 & 0.011 \\
\hline Protein & $211^{\mathrm{a}}$ & $218^{b}$ & $214^{\mathrm{ab}}$ & 1.9 & 0.011 \\
\hline Fat & $38^{b}$ & $21^{a}$ & $33^{b}$ & 1.9 & $<0.001$ \\
\hline Shear force value, $\mathrm{kg}\left(\mathrm{cm}^{2}\right)^{-1}$ & 13.2 & 12.1 & 11.3 & 1.74 & 0.727 \\
\hline Drip loss, \% & 0.78 & 0.88 & 0.93 & 0.127 & 0.700 \\
\hline \multicolumn{6}{|l|}{ Colour } \\
\hline “L” (lightness) & 37.2 & 36.2 & 36.6 & 0.63 & 0.484 \\
\hline “a” (redness) & $25.0^{\mathrm{ab}}$ & $22.7^{\mathrm{a}}$ & $25.7^{\mathrm{b}}$ & 0.68 & 0.015 \\
\hline "b" (yellowness) & 7.5 & 6.5 & 7.8 & 0.40 & 0.071 \\
\hline \multicolumn{6}{|l|}{ Sensory analysis } \\
\hline Tenderness & 5.5 & 5.6 & 5.6 & 0.27 & 0.934 \\
\hline Juiciness & 5.7 & 5.4 & 5.2 & 0.18 & 0.230 \\
\hline Beef flavour & 5.7 & 5.7 & 5.6 & 0.13 & 0.774 \\
\hline \multicolumn{6}{|l|}{ Marbling score } \\
\hline longissimus lumborum & $1.56^{\mathrm{b}}$ & $0.66^{a}$ & $1.25^{\mathrm{b}}$ & 0.151 & 0.001 \\
\hline longissimus thoracis & $1.34^{\mathrm{b}}$ & $0.25^{\mathrm{a}}$ & $0.94^{b}$ & 0.170 & $<0.001$ \\
\hline
\end{tabular}

Sensory analysis: scale from 1 to 7.

Marbling score: scale from 0 to 5 ( $0=$ devoid, $5=$ =abundant).

The longissimus lumborum $(p<0.01)$ and longissimus thoracis $(p<0.001)$ muscles of the Ab and AbxLi bulls had clearly higher marbling scores than those of the Li bulls but there were no significant differences in the marbling scores between the Ab and AbxLi bulls (Table 3 ). Breed had no significant effects on the lightness ( $L$ value) or yellowness ( $b$ value) of the longissimus lumborum muscle. However, the muscle redness ( $a$ value) was $13 \%$ higher in the Abx Li bulls than in the Li bulls $(p<0.05)$.

\section{Discussion}

Previous research has shown that when growing cattle of diverse breeds are compared at a similar age, with similar management, variation will be found in carcass weight, while carcass composition will depend on the range of target weights and differences in growth curves of each breed (Kempster et al. 1982, Alberti, et al. 2008). In agreement with our finding with grass silage-grain -based diet, Cuvelier et al. (2006a) reported no differences in LWG between Aberdeen Angus and Limousin bulls fattened with a sugar-beet pulp or a cereal-based diet and slaughtered at age 530 days. On the contrary, Alberti et al. (2008) observed that the average daily gain of Ab bulls was superior to Li bulls ( 1.97 vs. $1.46 \mathrm{~g} \mathrm{~d}^{-1}$ ) when both breeds were slaughtered at age 428 days and offered a concentrate diet. After all, Alberti et al. (2008) reported that Aberdeen Angus bulls showed a very high LWG during the experimental period ( 9 months to 12 months of age), and speculated that this may have been a result of compensatory growth. However, also Chambaz et al. (2003) found that Angus steers, reared until they reached the same intramuscular fat content, had a higher growth rate than Limousin steers. Then the average slaughter age, LWG and hot carcass weight for Angus and Limousin steers were 381 vs. 594 days, 1300 vs. $1030 \mathrm{~g} \mathrm{~d}^{-1}$ and 275 vs. 405 $\mathrm{kg}$, respectively (Chambaz et al. (2003). In the present study, the concentrate level used was rather low compared to many earlier experiments (e.g. Cuvelier et al. 2006a,b, Alberti et al. 2008) but, for example, in the study conducted by Chambaz et al. (2003) the diet consisted maize silage ( $\left.520 \mathrm{~g} \mathrm{~kg}^{-1} \mathrm{DM}\right)$, grass silage (260) and concentrate 
(220). Effects of concentrate level and feed intensity on performance and carcass traits of growing cattle are evaluated, for example, Caplis et al. (2005), Huuskonen et al. (2007), Manninen et al. (2010) and Randby et al. (2010).

The differences found among breeds in dressing proportion are in line with those observations found by Bonaïti et al. (1988), Wulf et al. (1996), Cuvelier et al. (2006a) and Alberti et al. (2008) for the Limousin breed and Barton and Pleasants (1997), Sinclair et al. (2001), Cuvelier et al. (2006a) and Alberti et al. (2008) for the Aberdeen Angus breed. For example, Bonaïti et al. (1988) observed a dressing proportion of $591 \mathrm{~g} \mathrm{~kg}^{-1}$ for Limousin bulls offered a diet based on dehydrated alfalfa and sugar beet pulp and slaughtered at 18 months old. For Aberdeen Angus bulls offered a concentrate diet, Cuvelier et al. (2006a) observed a dressing proportion of $550 \mathrm{~g} \mathrm{~kg}^{-1}$ while it was $548 \mathrm{~g}$ $\mathrm{kg}^{-1}$ with concentrate-finished Angus steers (Sinclair et al. 2001). In agreement with our findings, Chambaz et al. (2003) reported that carcasses of Angus steers had lower conformation scores compared to those of the Limousin steers when all animals had ad libitum access to the same diet consisting of maize silage, grass silage and concentrate. Similarly, Rødbotten et al. (2002) perceived that the Limousin crossbred bulls obtained higher scores for conformation than the Angus crossbred bulls. On the contrary, Alberti et al. (2008) observed no significant difference in conformation score between Angus and Limousin bulls offered a concentrate diet. In the present experiment the lower dressing proportion and conformation score of the Ab bulls can also be explained partly by their lower average slaughter weight compared to the Li bulls because it is established that these traits increase with increasing slaughter weight (Kempster et al. 1988).

The higher average fat score of Angus carcasses compared to late-maturing beef breeds is well documented (e.g. Chambaz et al. 2003, Bartoň et al. 2006, Alberti et al. 2008) and was observed also in the present experiment. Although measures of carcass fatness generally increase with increasing carcass weight (Keane and Allen 1998), the average carcass fat score of the $\mathrm{Ab}$ and $\mathrm{Ab} \times \mathrm{Li}$ bulls was clearly higher than that of the Li bulls at a constant age in our experiment. This is contrary to findings by Aass and Vangen (1998) who reported that sire breed differences in carcass fatness traits became insignificant when comparisons were made at a constant age instead of weight. However, carcass weights were considerably higher in the present study compared to those reported by Aass and Vangen (1998) (295, 304 and 319 kg for Angus, Hereford and Charolais bulls, respectively). In agreement with our results, Bartoň et al. (2006) concluded that, in general, the animals of earlier maturing breeds (Hereford, Angus) produced relatively more fat than later maturing ones (Charolais, Simmental) in spite of the fact that they were slaughtered at significantly lower live weights. This statement is supported by the present experiment with beef bulls slaughtered at heavy carcass weights. In accordance with Cuvelier et al. (2006a), meat of Ab bulls had higher lipid contents and lower protein content than that of Li bulls. These results indicate that the increase in lipid concentrations was associated with the decreased protein content, which is in accordance with the findings by Van Koevering et al. (1995).

A number of studies have confirmed a higher share of the most valuable cuts in the carcasses of Limousin breed compared to Angus breed (e.g. Oprządek et al. 2001, Cuvelier et al. 2006a, Alberti et al. 2008). For example, Oprządek et al. (2001) concluded that weight of valuable cuts showed significant differences among bulls of all studied breeds (Angus, Charolais, Hereford, Limousin, Simmental and Piedmontese Black-and-White $F_{1}$ crosses), and their share proved to be highest in the Limousin and Charolais and lowest in Hereford and Angus. Furthermore, Oprządek et al. (2001) reported that Limousines had more lean in valuable cuts than did other breeds, and Limousin bulls had the highest and Angus the lowest weight of tenderloin. The observed higher percentage of subcutaneous fat with Ab bulls compared to Li bulls in the present experiment is in line with results reported by Oprządek et al. (2001) and Alberti et al. (2008) and is caused by physiological differences between earlier and later maturing breeds. In agreement with our findings, also Alberti et al. (2008) observed that Li bulls had a lower percentage of bones compared to Ab bulls. Also Oprządek et al. (2001) reported that the highest percentage of bone in valuable cuts was observed in Hereford and Angus bulls (17.5\%), while the lowest was observed in Limousin bulls (13.9\%).

Similarly, as observed by Chambaz et al. (2003) and Cuvelier et al. (2006a,b), the pH of the carcasses was not significantly affected by the breed and was close to $\mathrm{pH} 5.5-5.6$, which is in agreement with data reported earlier 24 $\mathrm{h}$ post mortem (Manninen et al. 2011). In the present study there were only minor effects of breed on the muscle colour (redness was higher in the AbxLi bulls than in the Li bulls). In agreement, Chambaz et al. (2006) perceived no differences in meat colour between Angus and Limousin steers. Also Cuvelier et al. (2006a,b) observed no difference in redness or yellowness in the meat samples between purebred Aberdeen Angus and Limousin bulls. However, Cuvelier et al. $(2006 a, b)$ reported that the muscle lightness value was $6 \%$ higher for Li bulls than for Ab bulls.

In agreement with our findings, Rødbotten et al. (2002), Chambaz et al. (2006) and Cuvelier et al. (2006b) observed no effects on the shear force value between $\mathrm{Ab}$ and Li breeds. Instead, the present drip loss results disagree with findings by Chambaz et al. (2006) and Cuvelier et al. (2006b) who perceived that Angus animals had 
lower drip loss values compared to Limousin animals. The sensory evaluation reported by Chambaz et al. (2006), mainly agrees with our present findings that there were no differences between breeds. However, Chambaz et al. (2006) reported that differences between breed groups were found in juiciness, with the meat of the Limousin and, to a lesser extent that of the Charolais steers being juicier than that of the Simmental and particularly the Angus steers. In contrast, when comparing animals of the same age, Angus crosses with Charolais were found to yield the same tenderness as purebred Angus while crosses with Simmental and Limousin gave less tender meat (Koch et al. 1976). Even though several authors (e.g. Koch et al. 1979, Gregory et al. 1994, Wheeler et al. 1996) have reported a favourable relationship between marbling score (intramuscular fat content) and shear force/tenderness scores, in the present study there were no differences in shear force or tenderness scores among breeds though the $\mathrm{Ab}$ and $\mathrm{Ab} \times \mathrm{Li}$ bulls had clearly higher marbling scores than the Li bulls.

In conclusion, the limited material studied here shows that the best performance parameters were attained by the purebred Limousin bulls which produced the heaviest carcasses at the constant age and were superior for carcass conformation. The crossbred AbxLi bulls produced better conformed carcasses and a higher share of rounds compared to pure Angus bulls, which indicates that this type of crossbreeding can enhance beef production under the studied conditions.

\section{Acknowledgements}

This study was partially funded by the Centre for Economic Development, Transport and the Environment for Northern Ostrobothnia. We would like to thank Mr. Lauri Jauhiainen for advice on the statistical analyses. We wish to express our gratitude also to Mr. Mikko Piippo and Mrs. Jaana Piippo for technical assistance and their excellent care of the experimental animals. The personnel of the Lihakunta Slaughterhouse in Kuopio and the staff of the Finnish Meat Research Institute in Hämeenlinna are thanked for their help in slaughter procedures and meat evaluation.

\section{References}

Aass, L. \& Vangen, O. 1998. Carcass and meat quality characteristics of young bulls of Norwegian cattle and crossbreds with Angus, Hereford and Charolais. Acta Agriculturae Scandinavica, Section A, Animal Science 48: 65-75.

Alberti, P., Panea, B., Sañudo, C., Olleta, J.L., Ripoll, G., Ertbjerg, P., Christensen, M., Gigli, S., Failla, S., Concetti, S., Hocquette, J.F., Jailler, R., Rudel, S., Renend, G., Nute, G.R., Richardson, R.I. \& Williams, J.L. 2008. Live weight, body size and carcass characteristics of young bulls of fifteen European breeds. Livestock Science 114: 19-30.

Barton, R.A. \& Pleasants, A.B. 1997. Comparison of the carcass characteristics of steers of different breeds and pre-weaning environments slaughtered at 30 months of age. New Zealand Journal of Agricultural Research 40: 57-68.

Bartoň, L., Řehák, D., Teslík, V., Bureš, D. \& Zahrádková, R. 2006. Effect of breed on growth performance and carcass composition of Aberdeen Angus, Charolais, Hereford and Simmental bulls. Czech Journal of Animal Science 51: 47-53.

Berg, R.T., Andersen, B.B. \& Liboriusesen, T. 1978. Growth of bovine tissues. 1. Genetic influences on growth patterns of muscle, fat and bone in young bulls. Animal Production 26: 245-258.

Bonaïti, B., Bibé, B., Havy, A. \& Ménissier, F. 1988. Comparaison des races bovines Charolaise, Limousine et Maine-Anjou en race pure et en intercroisement. 3. Performances d'abattage des taurillons purs et F1. Génétique, Sélection, Evolution 20: 461-476.

Caplis, J., Keane, M.G., Moloney, A.P. \& O'Mara, F.B. 2005. Effects of supplementary concentrate level with grass silage, and separate or total mixed ration feeding, on performance and carcass traits of finishing steers. Irish Journal of Agricultural and Food Research 44: 27-43.

Chambaz, A., Scheeder, M.R.L., Kreuzer, M. \& Dufey, P.A. 2003. Meat quality of Angus, Simmental, Charolais and Limousin steers compared at the same intramuscular fat content. Meat Science 63: 491-500.

Commission of the European Communities. 1982. Commission of the European Communities (Beef Carcass Classification) Regulations. Council Regulations 1358/80, 1208/81, 1202/82. Commission Regulations 2938/81, 563/82, 1557/82, Brussels.

Cuvelier, C., Cabaraux, J.F., Dufrasne, I., Clinquart, A., Hocquette, J.F., Istasse, L. \& Hornick, J.-L. 2006a. Performance, slaughter characteristics and meat quality of young bulls from Belgian Blue, Limousin and Aberdeen Angus breeds fattened with a sugarbeet pulp or a cereal-based diet. Animal Science 82: 125-132.

Cuvelier, C., Clinquart, A., Hocquette, J.F., Cabaraux, J.F., Dufrasne, I., Istasse, L. \& Hornick, J.-L. 2006b. Comparison of composition and quality traits of meat from young finishing bulls from Belgian Blue, Limousin and Aberdeen Angus breeds. Meat Science 74: 522-531.

Gregory K.E., Cundiff L.V., Koch R.M., Dikeman M.E. \& Koohmaraie M. 1994. Breed effects and retained heterosis for growth, carcass, and meat traits in advanced generations of composite populations of beef cattle. Journal of Animal Science 72: 833-850.

Honkavaara, M., Rintasalo, E., Ylönen, J. \& Pudas, T. 2003. Meat quality and transport stress of cattle. Deutsche Tierärztliche Wochenschrift 110: 125-128.

Huida, L., Väätäinen, H., \& Lampila, M. 1986. Comparison of dry matter contents in grass silages as determined by oven drying and gas chromatographic water analysis. Annales Agriculturae Fenniae 25: 215-230. 
Huuskonen, A., Joki-Tokola, E., Honkavaara, M., Tuomisto, L. \& Kauppinen, R. 2010. Meat quality and fatty acid profile of M. longissimus dorsi of growing bulls under insulated, uninsulated and outdoor housing conditions. Agricultural and Food Science 19: 214-222.

Huuskonen, A., Khalili, H. \& Joki-Tokola, E. 2007. Effects of three different concentrate proportions and rapeseed meal supplement to grass silage on animal performance of dairy-breed bulls with TMR feeding. Livestock Science 110: 154-165.

Huuskonen, A., Pesonen, M. \& Hyrkäs, M. 2012. Liharotuisten sonnien ja hiehojen kasvu- ja teurasominaisuudet. Suomen Maataloustieteellisen Seuran Tiedote 29, 84 (Abstract). (in Finnish).

Huuskonen, A., Tuomisto, L., Joki-Tokola, E. \& Kauppinen, R. 2009. Animal performance and carcass characteristics of growing Hereford bulls under insulated, uninsulated and outdoor housing conditions in Northern Finland. Agricultural and Food Science 18: $16-26$

Karhula, T. \& Kässi, P. 2010. Lihanautatilojen taloudellinen tilanne Suomessa ja vertailumaissa. In: Arto Huuskonen (ed.). Kehitystä naudanlihantuotantoon I. [Towards more efficient beef production I]. Tampere, Finland: Tampereen yliopistopaino Juvenes Print Ltd. p. 9-34. (in Finnish with English Abstract).

Keane, M.G. \& Allen, P. 1998. Effects of production system intensity on performance, carcass composition and meat quality of beef cattle. Livestock Production Science 56: 203-214

Kempster A.J., Cook G.L. \& Southgate J.R. 1982. A comparison of the progeny of British Friesian dams and different sire breeds in 16- and 24-month beef production systems. 2. Carcass characteristics, and rate and efficiency of meat gain. Animal Production 34: 167-178.

Kempster A.J., Cook G.L. \& Southgate J.R. 1988. Evaluation of British Friesian, Canadian Holstein and beef breed $\times$ British Friesian steers slaughtered over a commercial range of fatness from 16-month and 24-month beef production systems. 2. Carcass characteristic, and rate and efficiency of lean gain. Animal Production 46: 365-378.

Koch, R.M., Dikeman, M.E., Allen, D.M., May, M., Crouse, J.D. \& Campion, D.R. 1976. Characterization of biological types of cattle. III. Carcass composition, quality and palatability. Journal of Animal Science 43: 48-62.

Koch, R.M., Dikeman, M.E., Jerry Lipsey, R., Allen, D.M. \& Crouse, J.D. 1979. Characterization of biological types of cattle - Cycle II: III. Carcass composition, quality and palatability. Journal of Animal Science 49: 448-460.

Koch, R.M., Dikeman, M.E. \& Crouse, J.D. 1982. Characterization of biological types of cattle (cycle III). III Carcass composition, quality and palatability. Journal of Animal Science 54: 35-45.

MAFF. 1984. Energy Allowances and Feeding Systems for Ruminants. ADAS Reference Book 433. Ministry of Agriculture, Fisheries and Food. London: Her Majesty`s Stationery Office. 85 p.

Manninen, M., Honkavaara, M., Jauhiainen, L., Nykänen, A. \& Heikkilä, A.-M. 2011. Effects of grass-red clover silage digestibility and concentrate protein concentration on performance, carcass value, eating quality and economy of finishing Hereford bulls reared in cold conditions. Agricultural and Food Science 20: 151-168.

Manninen, M., Jauhiainen, L., Ruusunen, M., Soveri, T., Koho, N. \& Pösö, R. 2010. Effects of concentrate type and level on the performance and health of finishing Hereford bulls given a grass silage-based diet and reared in cold conditions. Livestock Science 127: 227-237.

Moisio, T. \& Heikonen, M. 1989. A titration method for silage assessment. Animal Feed Science and Technology 22: 341-353.

MTT. 2012. Feed tables and nutrient requirements. [online]. Jokioinen: MTT Agrifood Research Finland. Cited 20 June 2012. Available at: http://www.mtt.fi/feedtables

Nousiainen, J., Ahvenjärvi, S., Rinne, M., Hellämäki, M. \& Huhtanen, P. 2004. Prediction of indigestible cell wall fraction of grass silage by near infrared reflectance spectroscopy. Animal Feed Science and Technology 115: 295-311.

Oprządek, J., Dymnicki, E., Oprządek, A., Słoniewski, K., Sakowski, T. \& Reklewski, Z. 2001. A note on the effect of breed on beef cattle carcass traits. Animal Science Paper and Reports 19: 79-89.

Poláh, P., Šubrt, J., Bjelka, M., Uttendorfský, K. \& Filipčík, R. 2004. Carcass value of the progeny of tested beef bulls. Czech Journal of Animal Science 49: 315-322.

Randby, Å.T., Nørgaard, P. \& Weisbjerg, M.R. 2010. Effect of increasing plant maturity in timothy-dominated grass silage on the performance of growing/finishing Norwegian Red bulls. Grass and Forage Science 65: 273-286.

Robelin, J. 1986. Growth of adipose tissue in cattle: partitioning between depots, chemical composition and cellularity. A review. Livestock Production Science 14: 249-264.

Rødbotten, R., Hildrum, K.I. \& Berg, J. 2002. Effects of concentrate level on carcass composition, tenderness and growth rate of Angus $\times$ NRF and Limousin $\times$ NRF bulls. Acta Agriculturae Scandinavica, Section A, Animal Science 52: 72-80.

Root, T. \& Huhtanen, P. 1998. Barley fibre and wet distillers' solubles in the diet of growing cattle. Agricultural and Food Science in Finland 7: 357-366.

Sinclair, K.D., Lobley, G.E., Horgan, G.W., Kyle, D.J., Porter, A.D., Matthews, K.R., Warkup, C.C. \& Maltin, C.A. 2001. Factors influencing beef eating quality -1 . Effects of nutritional regimen and genotype on organoleptic properties and instrumental texture. Animal Science 72: 269-277.

Sŭbrt, J., Frelich, J., Polach, P. \& Vořišková, J. 1999. Analysis of carcass quality in sons of breeding bulls of meat breeds. Czech Journal of Animal Science 44: 39-48.

Van Koevering M.T., Gill D.R., Owens F.N., Dolezal H.G., \& Strasia C.A. 1995. Effect of time on feed on performance of feedlot steers, carcass characteristics, and tenderness and composition of longissimus muscles. Journal of Animal Science 73: 21-28.

Wheeler, T.L., Cundiff, L.V., Koch, R. \& Crouse, J.D. 1996. Characterization of biological types of cattle (Cycle IV): Carcass traits and longissimus palatability. Journal of Animal Science 74: 1023-1035.

Wulf, D.M., Tatum, J.D., Green, R.D., Morgan, J.B., Golden, B.L. \& Smith, G.C. 1996. Genetic influences on beef longissimus palatability in Charolais- and Limousin-sired steers and heifers. Journal of Animal Science 74: 2394-2405. 